\title{
THE TRUMPETER SWAN
}

\author{
FRED C. BARD
}

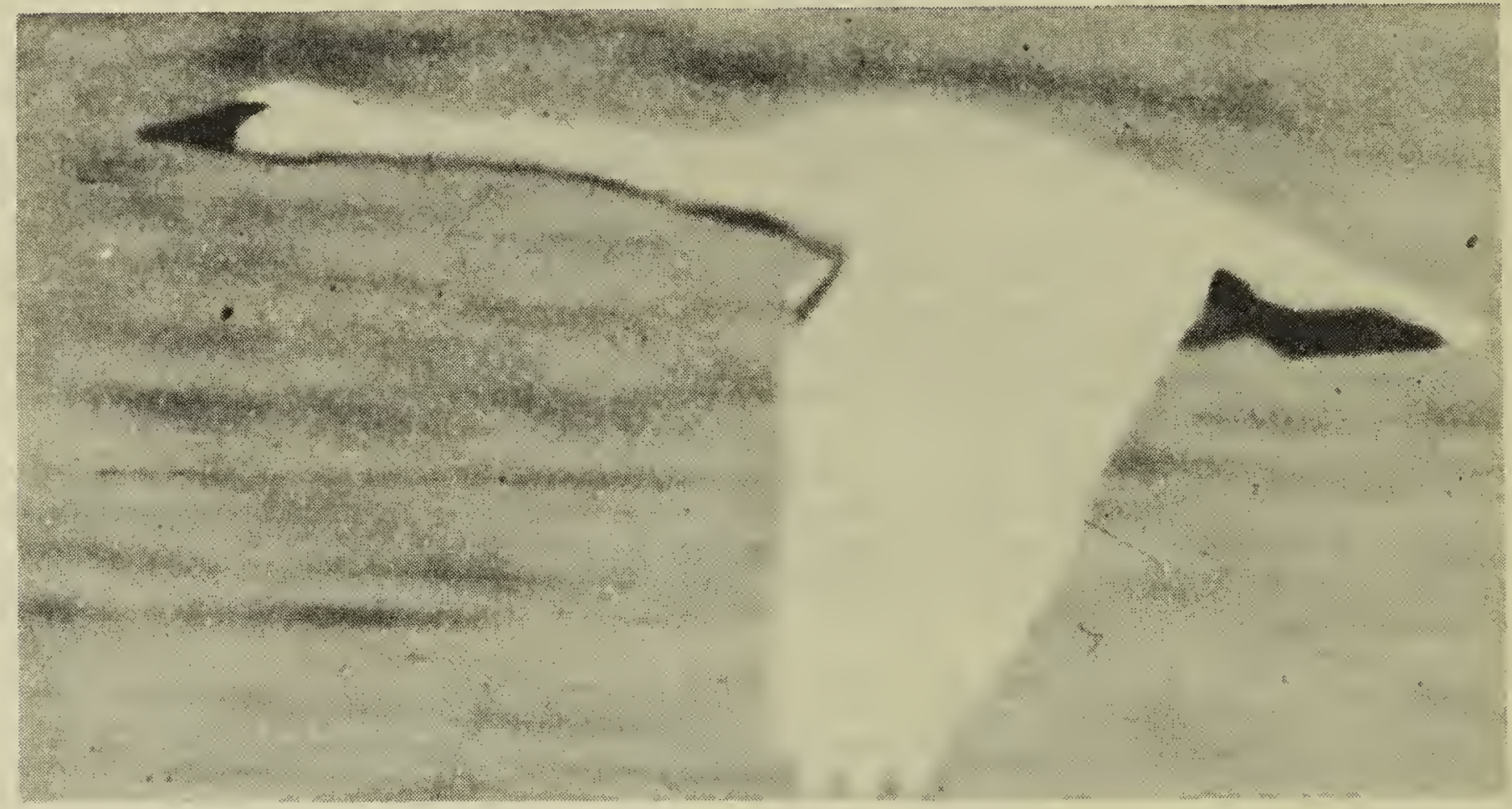

(Photos by Bard)

During the winter of 1953, Mr. and Mrs. George Naesmith of Maple Creek visited the Museum. They mentioned a Swan had been known to nest in the Cypress Hills. Swans in Saskatchewan during the summer are worth investigating and a promise was made to field check this record. On August 31st, Mrs. Naesmith accompanied Fred Lahrman and I to examine the two lakes where the bilds had been reported, one Adams Lake and the other Botley.

Travelling south from the Naesmith Ranch we crossed a height of land and dropped back into a deep coulee, and Adams Lake lay before us. Almost before we could stop, we saw a single white bird that we immediately took to be a Swan near the north end. With the sudden appearance of the car, the bird started to swim towards the south end of ihe lake.

We drove along the east side of the lake to get a better view of the Swan and, when opposite the bird, it turned and commenced swimming north again to decoy us away. The north end of the lake is divided by a peninsula that runs south for about 200 yards. The Swan soon disappeared in the west arm. The small heighth of land on the peninsula hid the bird from view. It was decided the car could play an important part in obtaining pictures. Mrs. Naesmith moved the car slowly up and down while Fred and I circled the north end of the lake and came in on the peninsula. As we approached the end of this point of land, we very cautiously, looked through cover in order to get a glimpse of the entire arm. We saw the Swan about a quarter of a mile further up the lake. We settled back and prepared the cameras, taking the necessary readings, etc., and, when hidden from view, the Swan could see the car moving towards the south and immediately headed in that direction. We took some pictures of the bird swimming closer when suddenly it turned north and took flight, swinging in a wide arc. it headed south. The Swan passed within a hundred yards of where we were hiding and our excitement ran high as we rose to obtain some record of this rare occasion. The bird continued south and, swinging around the bend, it disappeared. On reaching the car, we drove to the south end of the lake and found the female and a single well-grown young, grey in plumage, swimming close to the opposite shore. The male bird swam in by this time and the 
three started toward the north end of the lake.

During the morning we were able to obtain some pictures of the swimming birds and, on three occasions, heard the trumpetlike call of the female as she escorted the young away from new danger. Mr. Lahrman and I are well acquainted with the Whistling Swans and we recognized the great difference in the call of this bird. Now we had established the Trumpeter Swan as nesting in the Cypress Hills. The first definite recold for Saskatchewan so far as the Museum records show. Mrs. Naesmith told us the birds had not nested on this lake before and it was agreed we should visit Botley Lake. Following the coulee, along the creek we travelled nearly five milos before reaching Botley Lake. We covered this lake fairly well and found no evidence of any nest here, although towards the south the cover was much heavier. Yet we didn't see why these birds should leave Botley Lake and walk, as they would have to do, to take the young, and end up at Adams Lake over the height of land two miles away. It appeared food and cover was much better on this lake. We feel reasonably sure, therefore, the birds nested at Adams Lake.

It is interesting to note that Canada Geese, a pair with three young, were found on Botley Lake.

Photographs were made of this region and we returned to Adams Lake.

The afternoon was spent taking photographs of Adams Lake and the rolling hills in order to duplicate the scene in the habitat case. We were determined now to build a group of Trumpeter Swans. We had previously received two from the Canada Wildlife Service, birds that had died and' were given to us fol Museum mounts. More photographs were taken of the birds and, on each occasion, the male would swim to the north end to decoy us away. Here we left them until the next day.

On returning to the lake, the three birds were seen after considerable searching. The male was in evidence

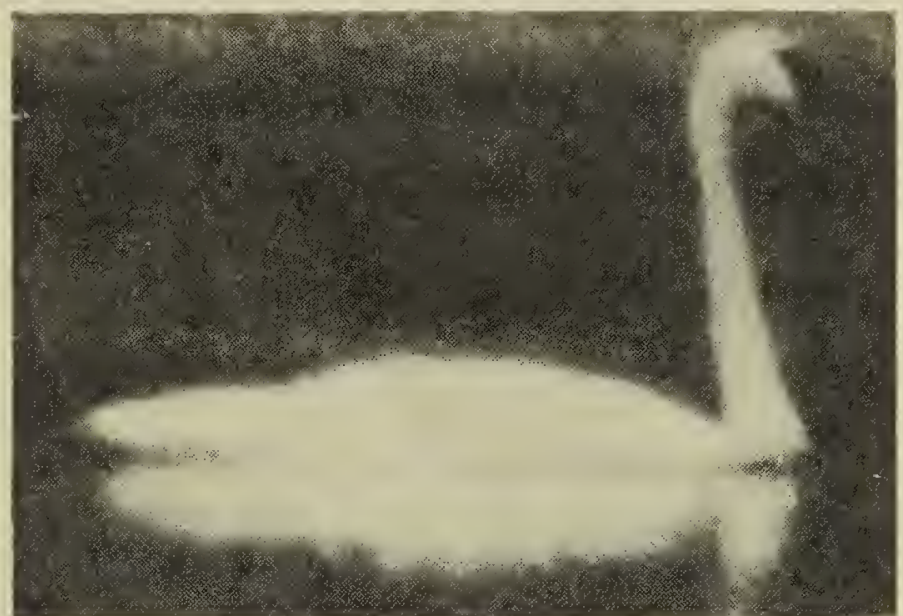

from the beginning, but the female and young had somehow managed to disappear in the cover near the spring on the opposite side of the lake. Two hours were spent recording the cover, taking photographs and motion pictures. About noon, we thought it advisable to leave the birds and continue with other field work. As we proceeded to leave, the male bird took flight and flew beyond the south end of the lake, swinging in an arc towards Botley Lake.

We are very pleased the birds have established themselves in the Hills and with reasonable protection, they should do well. It is interesting to note the recent Information Service Release by the Department of the Interior, the United States Fish and Wildlife Service, reports the Trumpeter Swan ranks continue to grow. A preliminary census, taken recently by Fish and Wildlife Service and National Park Service personnel, revealed an increase of 6 Trumpeters over last year's count of 571. The United States population now stands at 577 birds. We fully intend to keep a close check on this known pair in Saskatchewan and urge sufficient publicity to afford reasonable protection.

The larger species of wildlife are subject to targets far too often and, so far as the Trumpeter Swans and the Whooping Cranes are concerned, there is no excuse why these cannot be separated from the legal species of waterfowl that may be taken. We urge the sportsmen to take pride in their hunting cxpeditions in exercising the judgment of right from wrong. They alone will be responsible for the length of time these beautiful creatures continue to survive. 